\title{
Comprehension and production of spatial and non-spatial prepositions in specific language impairment children versus healthy children Based on cognitive linguistics
}

\author{
Saba Valizade ${ }^{1}$, Behrooz Mahmoodi Bakhtiari" (D), Mohammad Hadi Fallahi', Maryam Faham ${ }^{4}$ \\ 1. PhD Candidate, Department of Linguistics, Islamic Azad University, Science and Research Branch, Tehran, Iran \\ 2. Associate Professor, Department of Performing arts, Tehran University, Tehran, Iran \\ 3. Assistant Professor, Department of Computational Linguistics, Regional Information Center for Science and Technology, Shiraz University, Shiraz, Iran \\ 4. Assistant Professor, Department of Speech Therapy, Shiraz University of Medical Sciences, Shiraz, Iran
}

Recieved: 21 Feb. 2018

Revised: 24 Dec. 2018

Accepted: 24 Jan. 2019

Keywords

Cognitive linguistics

Spatial and Non-spatial prepositions

Specific language impairment

Corresponding author

Behrooz Mahmoodi Bakhtiari, Associate Professor, Department of Performing Arts, Tehran University, Tehran, Iran

Email: Mbakhtiari@ut.ac.ir

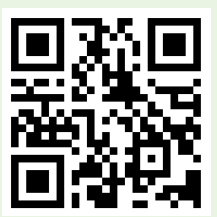

doi.org/10.30699/icss.21.4.103

\section{Abstract}

Introduction: Neuron revolution in linguistic theory has opened a new window to the understanding nature and function of brain and mind and their connection to the body based on the cognitive theory. Space words, which include spatial prepositions as well, stem from image schema in different languages. Therefore, of the objective of the present study was to understand and state spatial prepositions compared with non-spatial prepositions in children with specific language impairment (SLI) and healthy children (HC). Methods: The subjects consisted of eight Persian children with SLI aged 5-8 years, who were compared with the control group (eight HC peers). The children were investigated using a researcher-made test of comprehension and application of simple prepositions; the reliability and validity of the test were computed through a pretest of 60 normal 5 to 8-year old Persian children. Finally, the data were analyzed by SPSS using t-test Results: The results showed that the amount of comprehension and application of spatial prepositions among SLI children was lower than that in HC peers. Also, the amount of comprehension and application of non-spatial prepositions among SLI children was lower than that in HC peers.

Conclusion: Since spatial prepositions are space words and stem from image schema, thus, based on cognitive linguistics in confirmation of the non-modular function of the brain, SLI children demonstrated lower deficits in comprehension and production of spatial prepositions than non-spatial ones.

Citation: Valizade S, Mahmoodi Bakhtiari B, Fallahi MH, Faham M. Comprehension and production of spatial and non-spatial prepositions in specific language impairment children versus healthy children Based on cognitive linguistics. Advances in Cognitive Sciences. 2020;21(4):103-112. 


\title{
درك و بيان حروف اضافه مكانى و غيرمكانى در كودكان مبتلا به آسيب ويزه زبانى در مقايسه با كودكان طبيعى در جار جوب
}

\section{زبانشناسى شناختى}

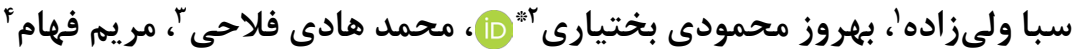

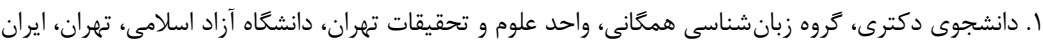

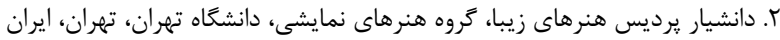

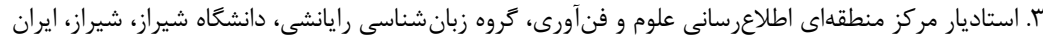

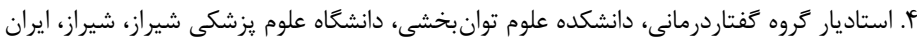

\section{(2)}

مقدمه: انقلاب نورونى در نظريه زبانى به درك ماهيت و عملكرد مغز و ذهن و پيوند آنها با بدن در خارجوب نظريه شناختى دريجهاى نوين گشوده است. وارههاى فضايى كه حروف اضافه مكانى را نيز شامل مىشوند، در زبانهاى مختلف ريشه در طرحوارههاى تصويرى دارند. بنابراين هدف اين يزوهش جُكَونكى درك و بيان حروف اضافه مكانى در مقايسه با

$$
\text { غيرمكانىها در كودكان مبتلا به آسيب ويثه زبانى و كودكان طبيعى بود. }
$$
روش كار: آزمودنىها شامل ^ كودى ه تا 1 ساله فارسى زبان مبتلا به آسيب ويثه زبانى بود كه با كروه شاهد (1 كودى همتاى ساله) مقايسه شدند. نمونه ها با استفاده از آزمون محقق ساخته درك و كاربرد حروف اضافه ساده كه يايايى و روايى آن از طريق ييش آزمون •و كودى ه تا ^ ساله فارسى زبان سالم محاسبه شد، ارزيابى شدند. در نهايت، دادهها با استفاده

$$
\text { از آزمون t و با نرمافزار SPSS تجزيه و تحليل شدند. }
$$

يافته ها: نتايج نشان داد ميزان درى و كاربرد حروف اضافه ساده مكانى در كودكان مبتلا به آسيب ويزه زبانى كمتر از كودكان طبيعى بود. همجنين در كودكان مبتلا به آسيب ويزه زبانى ميزان درك و كاربرد حروف اضافه غيرمكانى كمتر

$$
\text { از ميزان درى و كاربرد حروف اضافه مكانى بود. }
$$

نتيجهَّيرى: از آن جا كه حروف اضافه مكانى، وازثهاى فضايى هستند و ريشه در طرحوارههاى تصويرى دارند، بنابراين در خارجوب زبانشناسى شناختى در تأييد عملكرد غيرحوزهاى مغز، كودكان مبتلا به آسيب ويزه زبانى در درك و استفاده

$$
\text { از حروف اضافه مكانى اختلالات كمترى نسبت به غيرمكانىها نشان دادند. }
$$

دريافت:

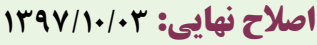

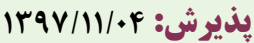
واثرهاى كليدى زبان شناسى شناختى حروف اضافه مكانى و غيرمكانى آسيب ويزه زبانى إضى مكرف إنى

نويسنله مسئول

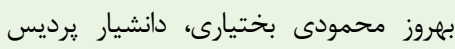
هنر هاى زيبا، كَروه هنرهاى نمايشى، دانشخاه

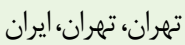

ايميل:Mbakhtiari@ut.ac.ir

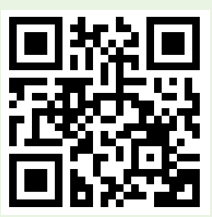

dol doi.org/10.30699/icss.21.4.103
رويكردى به مطالعه زبان يا به عرصه وجود كذاشت و همواره در اين راه مى كوشد، اما در حال حاضر اين رويكرد، تلويحات و كاربردهايى بسيار فراتر از مطالعه زبان در معناى سنتى آن دارد (1). به زعم نعارند أن يكى از نوينترين جنبه هاى زبانشناسى، مطالعات و يزوهش هاى مشترك علمى بين زبانشناسى، عصبشناسى و آسيبشناسى زبان و كفتار است
زبانشناسى شناختى رويكردى به مطالعه زبان است كه در آن توانايى زبانى انسان متمايز از ديخر توانايىهاى شناختى وى در نظر گرفته نمىشود. فراخيرى و يردازش زبان تفاوت جندانى با انواع ديگر قواى شناختى ندارد؛ بدين معنى كه درك زبان و ديگر جنبه هاى تفكر از فرآيندهاى شناختى يكسانى بهره مى گيرند. اخرجه زبانشناسى شناختى در آغاز به عنوان 
نيز به لحاظ تاريخى ممكن است دهار تغيير و تطور شده باشند. معانى حروف اضافه مكانى بر اساس تجربه ما از مكان معين مىشوند، به عبارت ديخر معانى مربوط به مكان به تجربه نزديكترند و بر اساس طرحواره

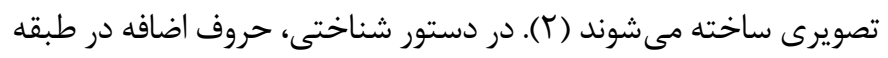

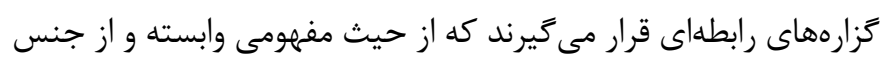

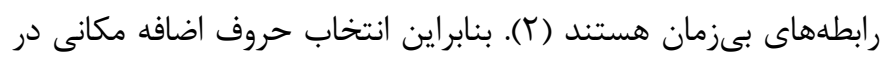

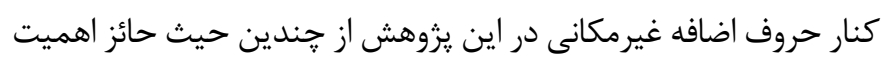
است؛ اول آنكه هر دو نوع حرف اضافه، نقشهاى دستورى ايفا مى كنند و به طبقه وازمهاى دستورى تعلق دارند اما به لحاظ طبقهبندى دستور شناختى به لحاظ مفهومسازى بدنمند با يكديكر متفاوتند. دومين دليل انتخاب حروف اضافه اختلالى است كه كودكان مبتلا به آسيب ويزه زبانى در درى و كاربرد وازههاى دستورى بروز مى دهند.

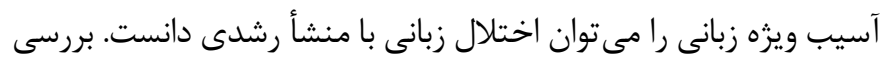

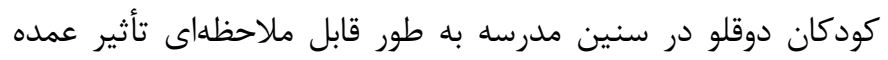

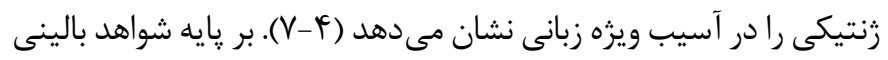

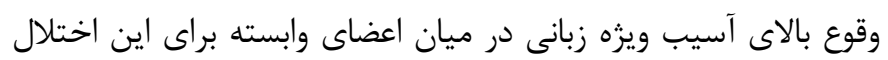

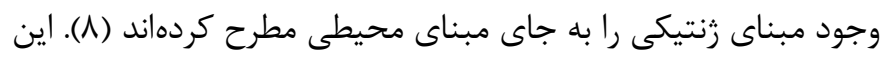

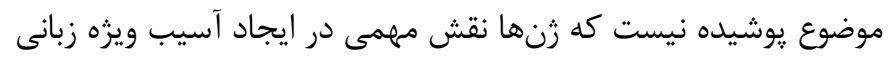

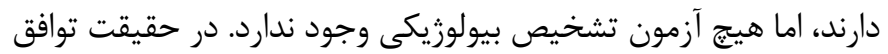

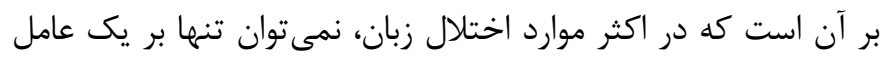

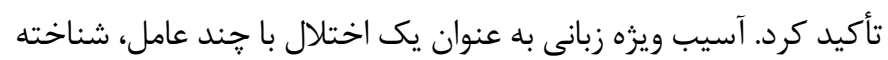

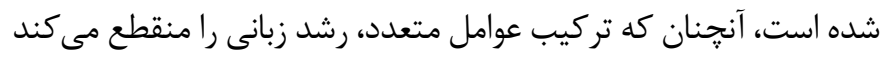

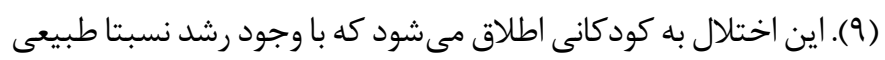

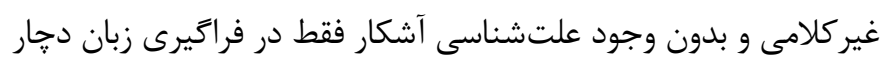

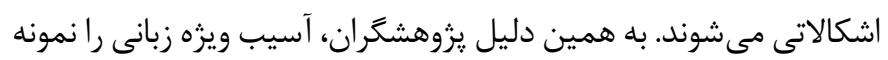

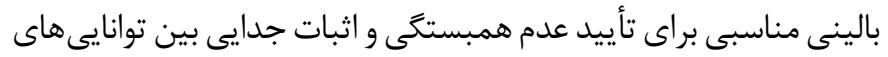

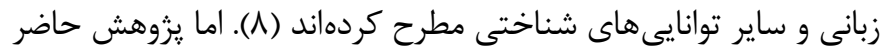

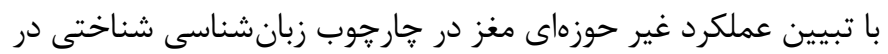

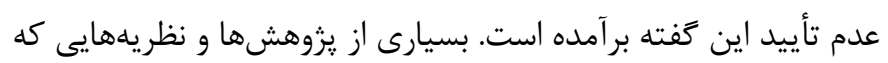

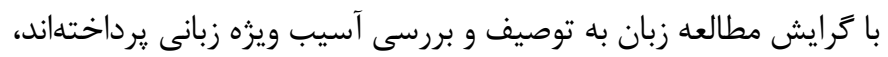

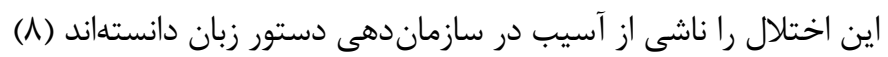

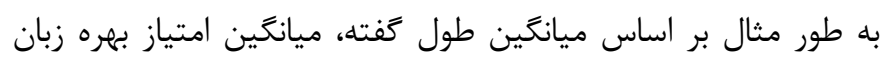

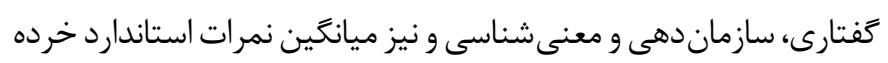

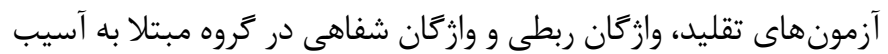
ويزه زبانى به طور معنادارى بايين تر از گروه كنترل همتاى زبانى آنهاست.

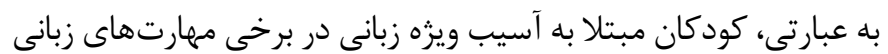
ماند ميانكين طول كفته، از كودكان همتاى خود عقبترند (• (1). در
كه به پِيدايش علم زبانشناسى بالينى منجر گَشته است. زبانشناسى بالينى به مطالعه اختلالات زبان و كفتار يرداخته و از طرفى با بررسى زبان بانيان

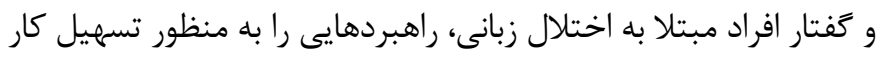

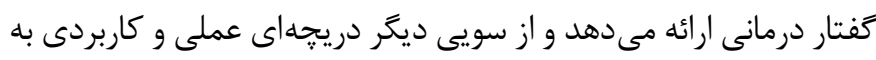

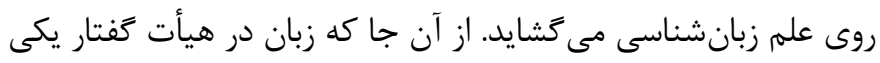

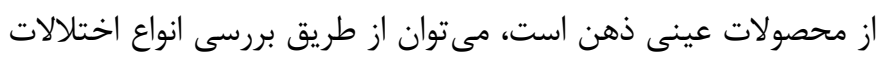

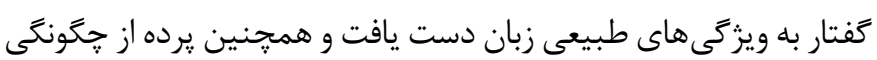
فراكيرى زبان اول برداشت. نظر به اين كه زبانشناسى شناختى با تكيه بر اصل تعميم، نكرش حوزهاى در مطالعه زبان را نمى يذيرد و بر اين نكته

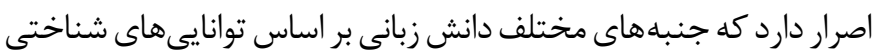

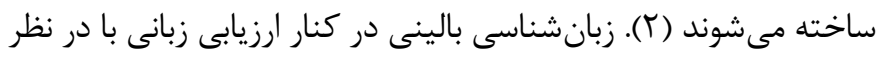

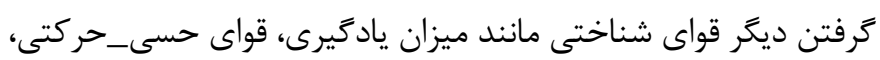

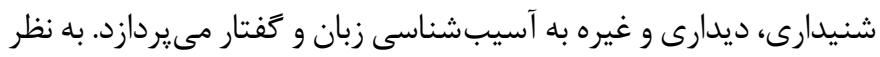
مىرسد رويكرد زبانشناسى شناختى به دليل ارزيابى زبان در كنار ديخر

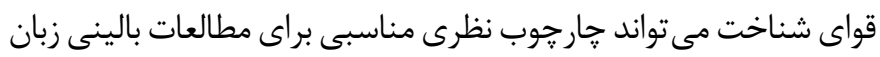

$$
\text { و كفتار قرار گيرد. }
$$

وازههاى فضايى در زبانهاى مختلف اساس جسمانى دارند، مثل بالا و ״ايين، جֶ و راست، جلو و عقب به عبارت ديكر از تجارب بدن مند ما نسبت به محيط خارج نشأت مى گيرند (؟َ). بنابراين حروف اضافه مكانى

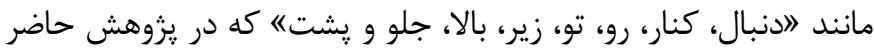

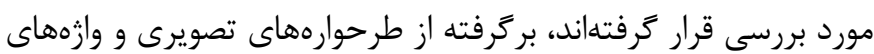

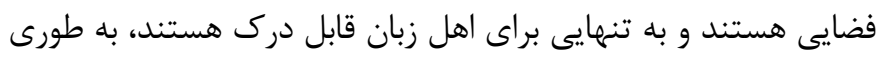

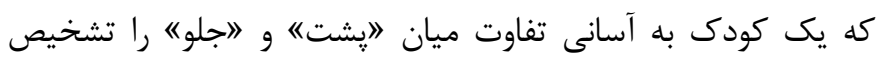

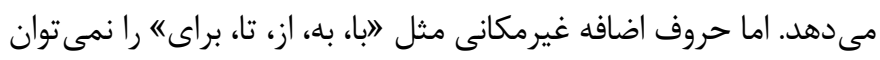
به لحاظ زبانشناسى شناختى جزء وازمهاى فضايى به حساب آورد، جرا كه مستقيما به محيط خارج ارجاع داده نمىشوند بلكه به وسيله ابزار

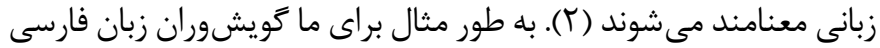

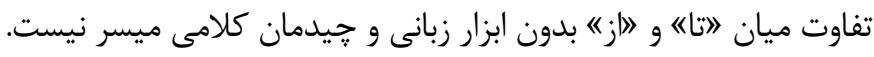

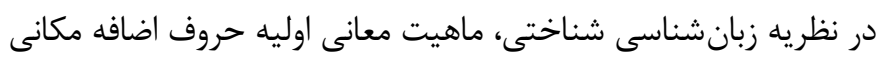

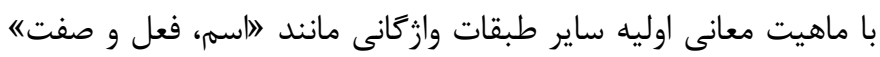
متفاوت است، جرا كه حروف اضافه مكانى بيان كر روابطى مكانى هستند ماند

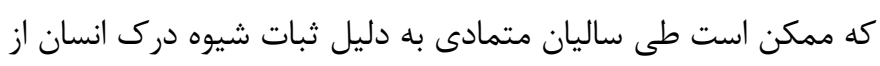

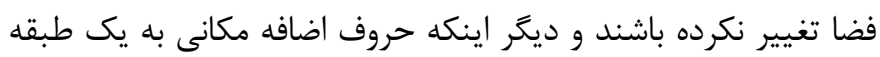

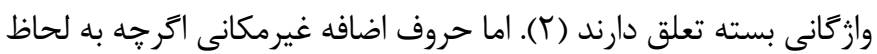
طبقه وازكانى مانند حروف اضافه مكانى بسته هستند و در گروه وازههاى

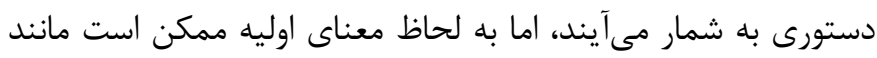
ديخر طبقهاى وازَّانى عمل كنند زيرا جزء وازههاى فضايى نيستند و 
فارسى اختلالات ويزه زبانى (^)، متناسب با معيارها و استانداردهاى

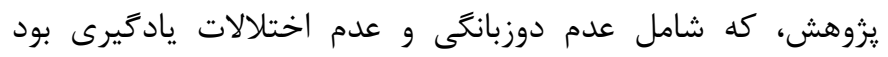
تنها صحت اختلال ^ كودى تأييد شد، باقى كودكان مشكوك به به

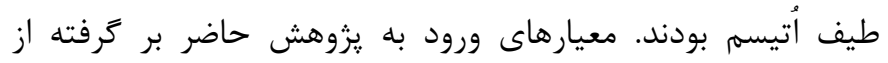
استانداردهاى موجود در آزمون فارسى اختلالات ويزه زبانى بود (^).

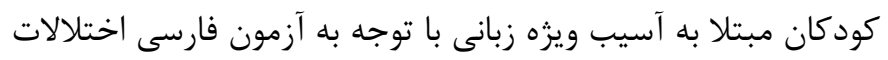

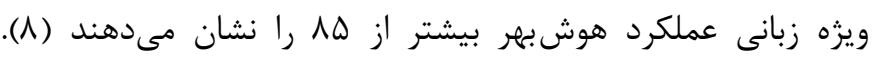

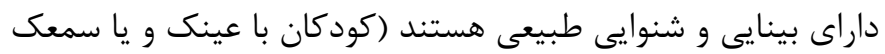
وارد جامعه آمارى نشدند). دجار سندرم خاصى نيستند. عقبماندىى لئى

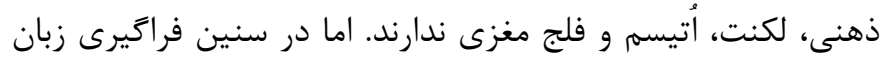

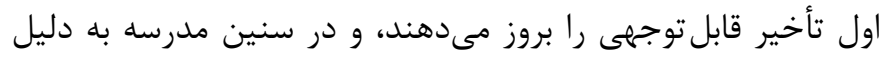
اختلال توليد، نارساخوانى و اختلال يادكيرى عمدتا توسط معلمان به

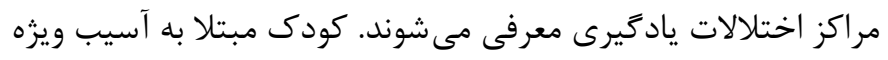

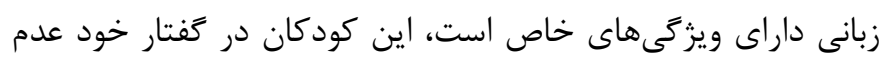

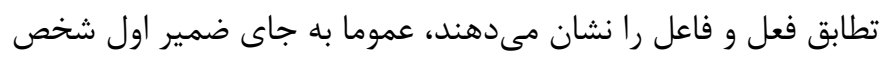

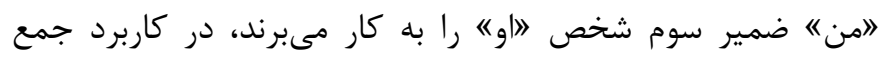
》ها《 دجار مشكل هستند، زمان افعال را به درستى به كار نمىبرند، در كاربرد تكوازهاى اشتقاقى اشتباه مى كنند، در تكرار ناوازمها عمدتا

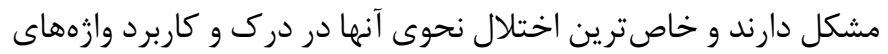
دستورى است (^). از اين روى تنها 1 آزمودنى با آسيب ويزه زبانى دانى

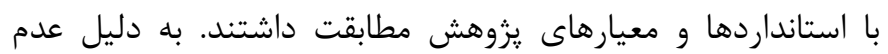

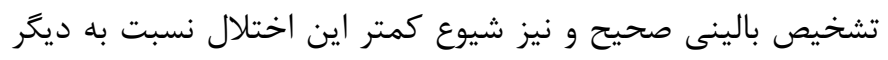

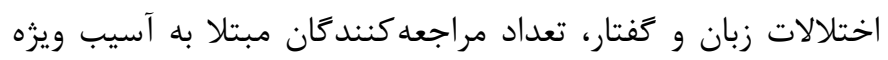

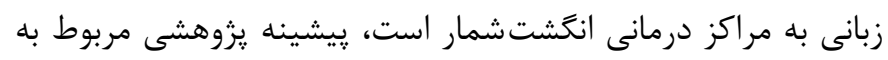

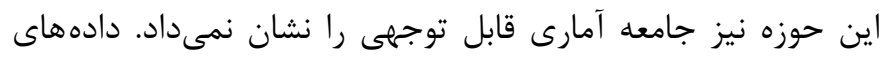

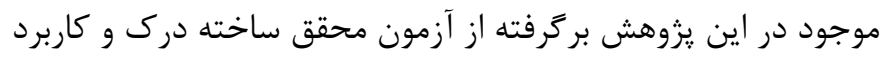

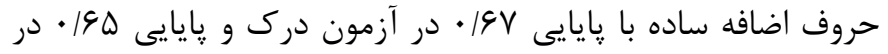

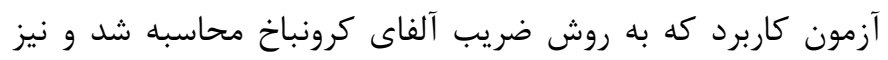

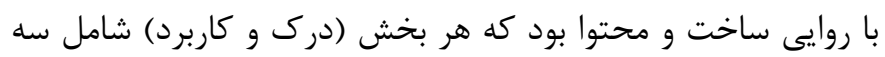

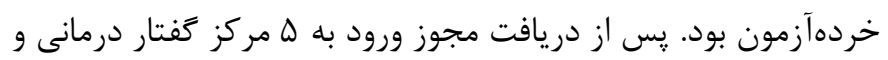

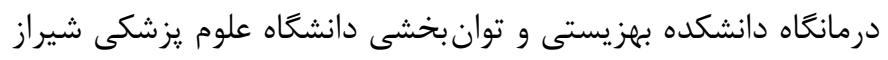

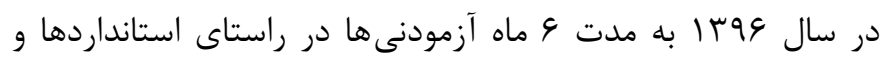

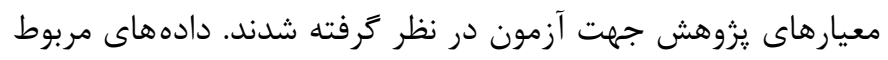

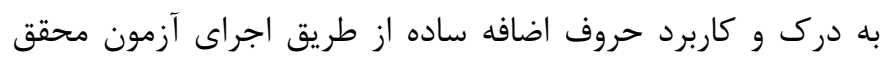

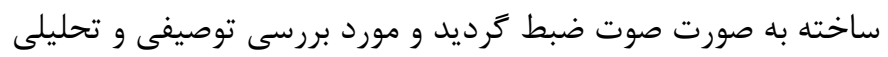
قرار كرفت. به منظور تجزيه و تحليل دادهها به لحاظ كمى، داده هاى خام آزمون درك به روش اسمى يعنى • و ا (به هر جمله درست
تحقيقى ديگر ثابت شده است كه مشكلات زبانى كودكان مبتلا به آسيب ويزه زبانى باعث مىشود كه اين كودكان نتوانند فرايند كاملى از تعريف

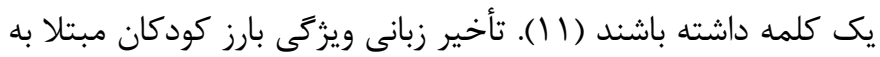

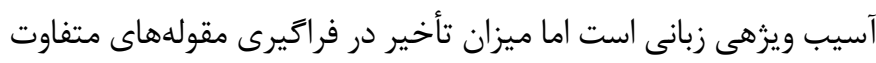
زبان متغير است. اختلالات نحوى نيز از ديكر ويزَّيهاى مهم كودكان

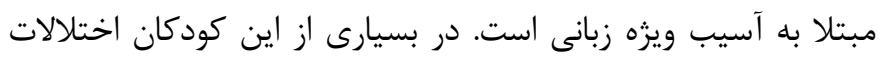

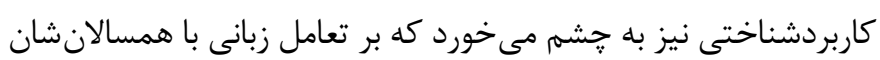

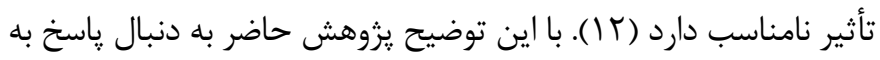
اين يرسش است كه آيا در خار جوب زبان شناسى شناختى، درك و كاربرد حروف اضافه مكانى و غيرمكانى در كودكان با آسيب ويزه زبانى مشابه كودكان همتاى طبيعى است؟

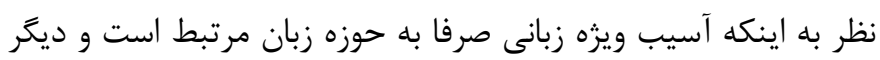

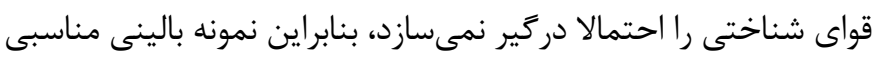

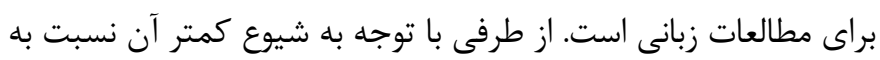

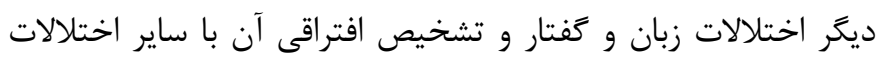

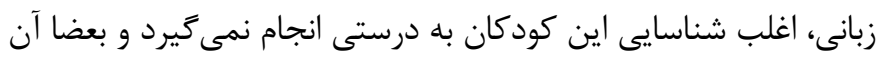

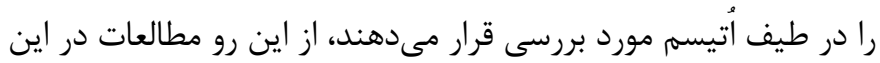

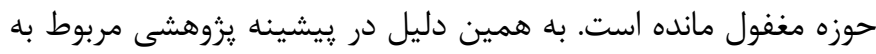
اين حوزه، يزوهشهاى ييشين داخلى و خارجى صرف نظر از ديخر قواى برى درين

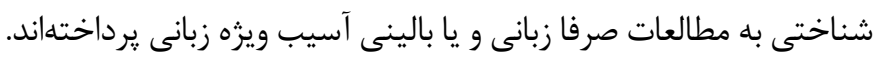

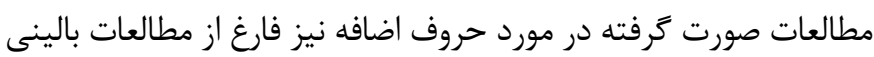

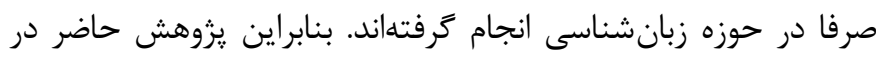

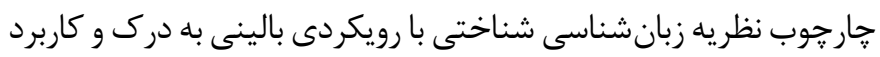

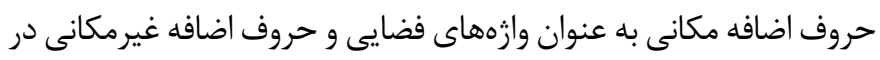

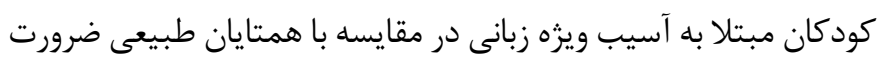
مىيابد. به عبارت ديكر هدف اين مختصر، جَّونكى درك و استفاده از حروف اضافه ساده مكانى (كنار، تو، رو، زير، يشت، بالا، دنبال، جلو) و

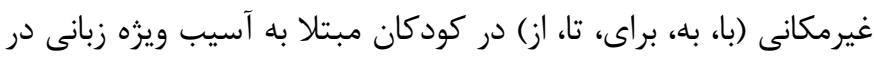

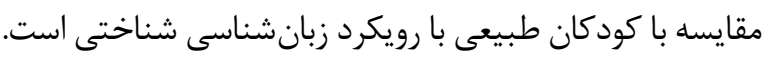

\section{روش كار}

اين يزوهش به روش توصيفى_تحليلى بر مبناى نظريه زبان شناسى

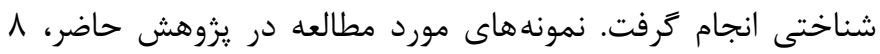

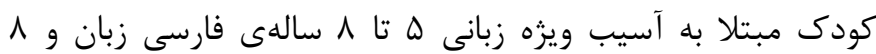

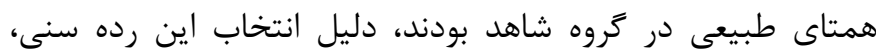
بروز اين اختلال در سنين اوليه مدرسه بود (^). يس از بررسى سوابق

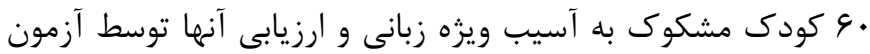


حروف اضافه در همتايان طبيعى بيشتر بود.

تفاوت ميزان درك حروف اضافه مكانى در كودكان مبتلا به آسيب ويزه زبانى با همتايان طبيعى ديى درو

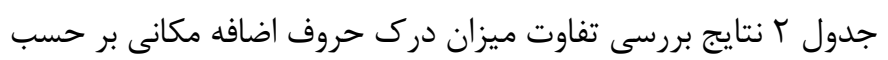

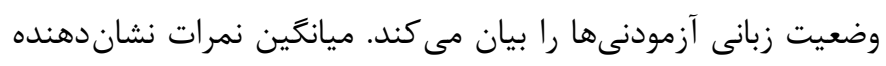

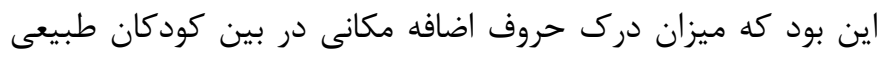

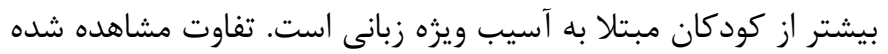
بين دو ميانگَين بر اساس آزمون t بيانكر تفاوت معنادار بين كودكان

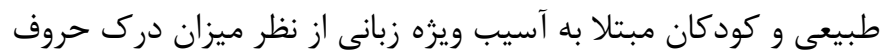

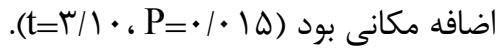

تفاوت ميزان كاربرد حروف اضافه غيرمكانى در كودكان مبتلا به آسيب ويزه زبانى با همتايان طبيعى مئى

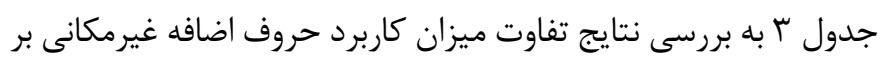

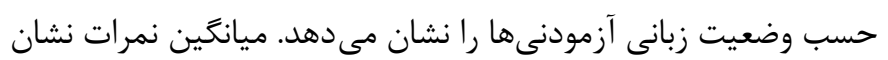

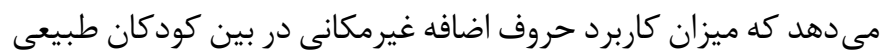
بيشتر از كودكان مبتلا به آسيب ويزه زبانى است. تفاوت مشاهده شده بين دو ميانگين بر اساس آزمون t بيان كر تفاوت معنادار بين كودكان

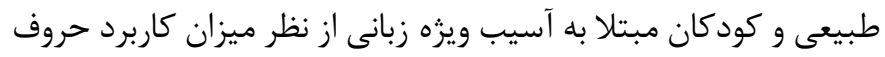

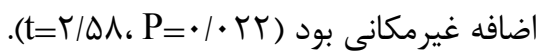

تفاوت ميزان كاربرد حروف اضافه مكانى در كودكان مبتلا به

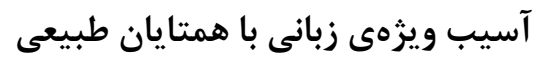

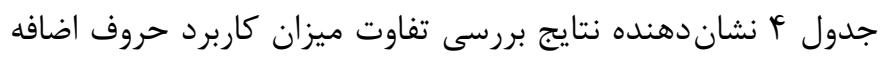

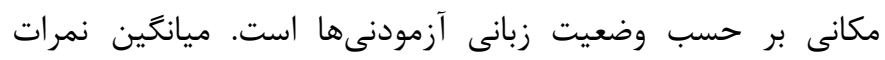
بيانگر ميانكَين بيشتر در ميزان كاربرد حروف اضافه مكانى، در بين كودكان طبيعى بود. تفاوت مشاهده شده بين دو ميانگَين بر اساس

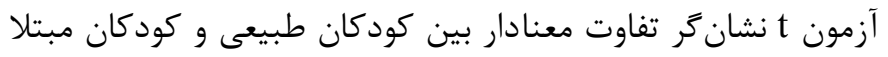

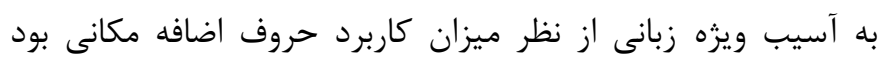
( $(\mathrm{t}=\mathrm{r} / \mathrm{F} \mathrm{V}, \mathrm{P}=\cdot / \cdot r V)$

يافتهها به لحاظ تحليلى و توصيفى نشان دادند كه كودكان مبتلا به

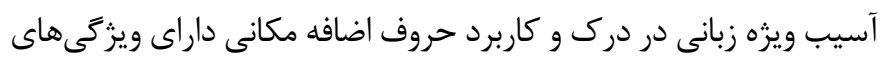

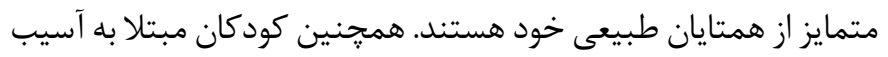

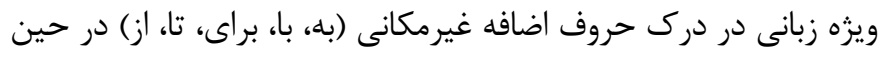

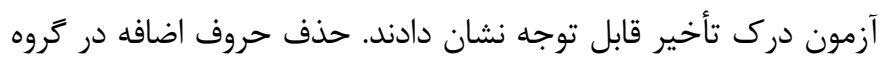
حرف اضافهاى از نشانههاى بارز مشكلات نحوى كودكان مبتلا به آسيب
نمره ا و به هر جمله غلط نمره • داده شد) و دادههاى خام آزمون

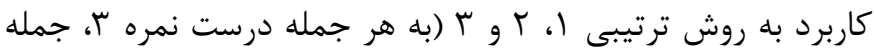

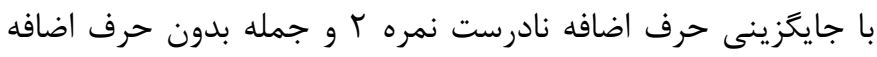

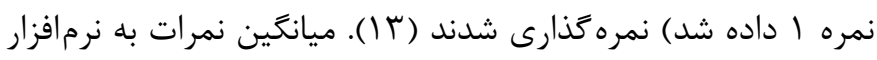

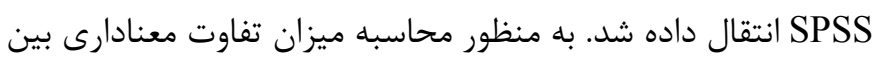
دو از آزمون t استفاده شد.

\section{يافته ها}

در جار جوب نظريه زبانشناسى شناختى طبق نظريه فضاهاى ذهنى، به هنكام صحبت كردن و يا فكر كردن، فضاهاى ذهنى ساخته مى شوند

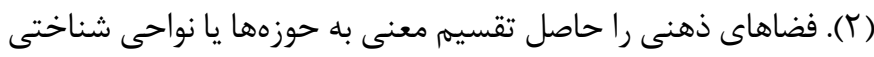

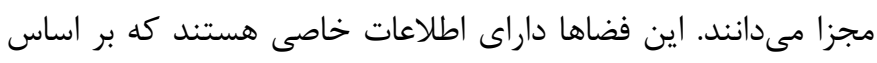

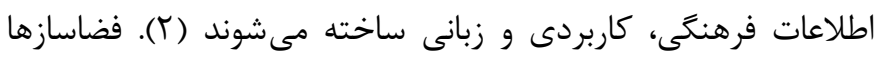

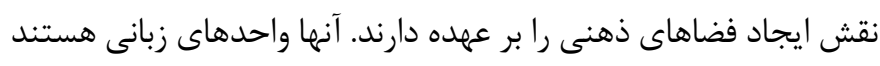

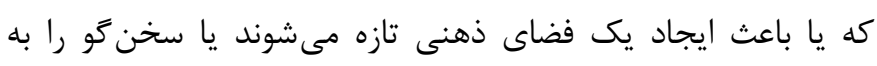

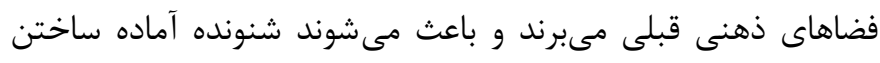

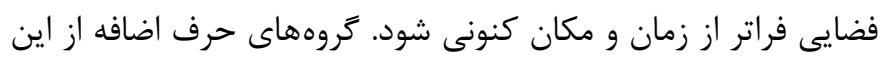

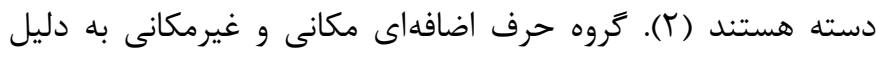

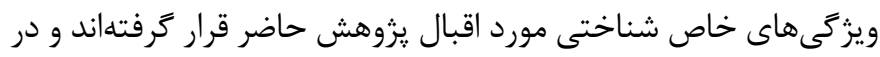

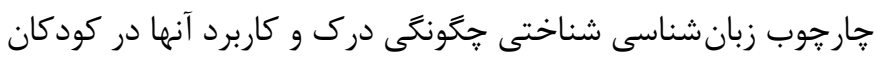

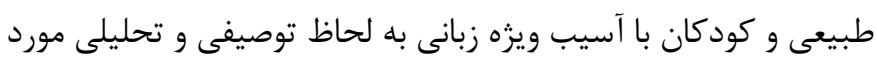

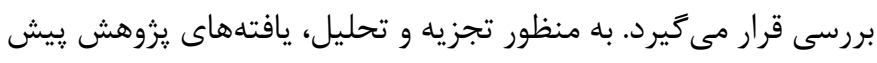

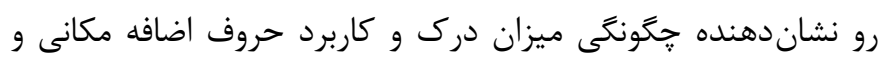

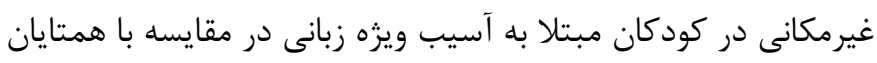

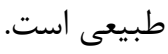

تفاوت ميزان درك حروف اضافه غيرمكانى در كودكان مبتلا به

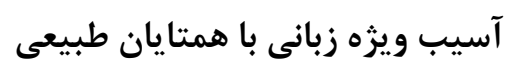

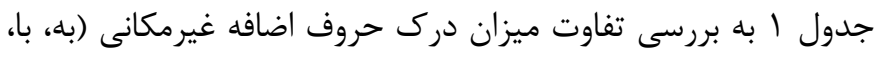
براى، از، تا) بر حسب وضعيت زبانى آزمودنى ها برداخته است. بردئ ميانكَين نمرات حاكى است كه ميزان درك حروف اضافه غيرمكانى، در بين آنس

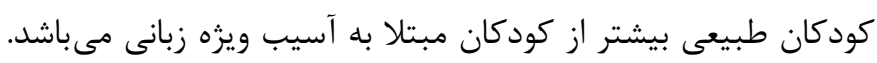

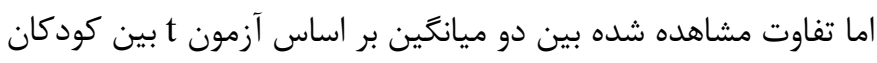

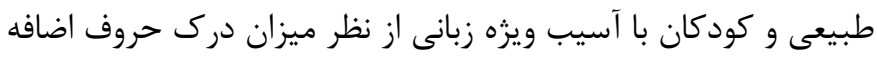

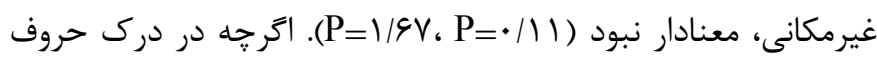
اضافه غيرمكانى ميان كودكان طبيعى و كودكان مبتلا به آسيب ويزه زبانى تفاوت معنادارى وجود ندارد اما ميزان ميانخين درك اين كروه از 
مكانى و غيرمكانى در كودكان مبتلا به آسيب ويزه زبانى وجود داشت

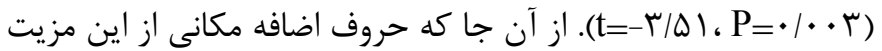
برخوردارند كه نشان فيزيكى قابل مشاهدهاند و اين روابط با اشيايى سر و كار دارند كه نسبت به يكديگر ساكن مى باشند (I I )، مبتلايان به آسيب ويزه زبانى در كاربرد حروف اضافه مكانى موفقيت بيشترى را نسبت به كاربرد حروف اضافه غيرمكانى بروز دادند. مىتوان اين موضوع را به درك

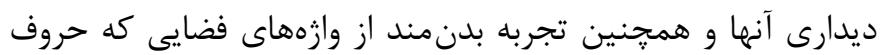
اضافه مكانى (تو، زير، رو، بالا، كنار، يشت، دنبال، جلو) را نيز شامل مى شوند مربوط دانست. در آزمونهاى زبانى اندازهخيرى درى مقولههاى زبانى و توصيف آن از اندازهگيرى و توصيف كاربرد آنها دشوارتر است. اما در يديده فراگيرى زبان به ويزه فراتيرى زبان اول، درك مرحله آغازين زبان است به عبارت ديخر تا درك زبانى اتفاق نيفتد بيان و كاربرد زبان در هيأت كفتار انجام نمى يذيرد. بنابراين نتايج آزمونهاى كاربرد را مى توان به به به آزمونهاى درك نيز تعميم داد. نمونه هاى مبتلا به آسيب ويزه زبانى در اين يزوهش در كابرد و بيان حروف اضافه مكانى عملكردى متفاوت نسبت به حروف اضافه غيرمكانى داشتند. rی درصد از نمونه آهاى مبتلا به آسيب ويزه زبانى در كاربرد و بيان حروف اضافه (تو، رو، بالا، زير، دنبال، يشت، جلو، كنار) درست عمل كردند اما IV درصد از آنها همانند عملكرد صد در صدى نمونههاى مبتلا به آسيب ويزه زبانى در مورد حروف اضافه غيرمكانى يا حروف اضافه را كاملا از زروه حرف اضافهاى حذف كردند. مانند حذف "اباه در جملهى "با مداد مىنويسد" كه جمله توليد شده توسط نمونه مبتلا به آسيب ويزه زبانى "مداد مىنويسد" است. يا اين كه جايگزينى نادرست حروف اضافه توسط نمونههاى مبتلا به آسيب ويزه زبانى صورت گرفته است كه عموما حرف اضافه غيرمكانى 》به" جايخزين 》باه شده است، مثلا نمونه مبتلا به آسيب ويزه زبانى به جاى استفاده از حرف اضافه غيرمكانى لبا《 از حرف اضافه غيرمكانى "به" در جمله "به من بازى كن" بهره برده است.
ويثه زبانى بود، به طور مثال كودكان مبتلا به آسيب ويره زبانى در حين

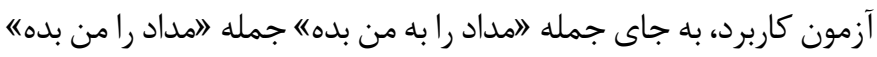
توليد كردند. اين مشكل مىتواند در حوزه درك نيز اختلال ايجاد كند به عبارت ديخر احتمال دارد كودكان مبتلا به آسيب ويزه زبانى از حروف اضافه غير مكانى مانند ابه" هيج دركى نداشته باشند.

\section{تفاوت ميزان درك حروف اضافه مكانى و غير مكانى در كودكان مبتلا به آسيب ويثره زبانى} جدول ه نتايج بررسى تفاوت ميزان درك حروف اضافه مكانى و غيرمكانى در بين كودكان مبتلا به آسيب ويزه زبانى را نشان مىدهد. ميانگين نمرات حاكى است كه ميزان درك حروف اضافه مكانى در كودكان مبتلا به آسيب ويره زبانى بيشتر مىباشد. اما تفاوت مشاهده شده بين دو ميانگين بر اساس آزمون t بيان خر اين بود كه تفاوت معنادارى بين ميزان درك حروف اضافه مكانى و غيرمكانى در بين كودكان مبتلا به آسيب ويزه

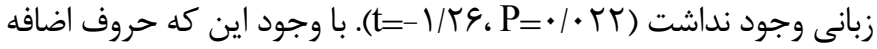
مكانى بيانگر روابط فيزيكى هستند و حروف اضافه غير مكانى اين روابط را نشان نمى دهند (f ( ). دادهاى اين يزوهش نشاندهنده عدم توجه

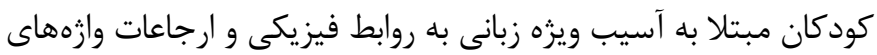
دستورى به محيط خارج بود جرا كه تفاوت معنادارى در ميزان درك دو گروه حروف اضافه مكانى و غير مكانى وجود نداشت. اين عدم توجه را مى توان به درك شنيدارى آنها مربوط دانست.

\section{تفاوت ميزان كاربرد حروف اضافه مكانى و غير مكانى در كودكان مبتلا به آسيب ويزه زبانى} جدول \& نتايج بررسى تفاوت ميزان كاربرد حروف اضافه مكانى و غيرمكانى در كودكان مبتلا به آسيب ويزه زبانى را نشان مى دهد. ميانگين نمرات حاكى از آن بود كه ميزان كاربرد حروف اضافه مكانى، بيشتر است. تفاوت مشاهده شده بر اساس آزمون t نشان دهنده اين بود كه تفاوت معنادارى بين ميزان كاربرد حروف اضافه

جدول ا. تفاوت ميزان درك حروف اضافه غيرمكانى در كودكان مبتلا به آسيب ويزه زبانى با همتايان طبيعى

\begin{tabular}{|c|c|c|c|c|c|}
\hline $\mathbf{p}$ & $\mathbf{t}$ & انحر اف معيار & ميانَين & فراوانى & تروه \\
\hline \multirow{2}{*}{.$- / 11 \mathrm{~V}$} & \multirow{2}{*}{$1 / 9 V$} & $\Gamma / M$ & $\| F / v \Delta$ & $\wedge$ & طبيعى \\
\hline & & $r$ & Ir & $\wedge$ & آسيب ويزه زبانى \\
\hline
\end{tabular}


جدول r. تفاوت ميزان درك حروف اضافه مكانى در كودكان مبتلا به آسيب ويزه زبانى با همتايان طبيعى

\begin{tabular}{|c|c|c|c|c|c|}
\hline $\mathbf{p}$ & $\mathbf{t}$ & انحراف معيار & ميانگين & فراوانى & گ گروه \\
\hline \multirow{2}{*}{$.1 \cdot 10$} & \multirow{2}{*}{$r / l}$. & . /9T & $19 / 0$. & $\wedge$ & طبيعى \\
\hline & & r & 10 & $\wedge$ & آسيب ويثه زبانى \\
\hline
\end{tabular}

جدول r. تفاوت ميزان كاربرد حروف اضافه غيرمكانى در كودكان مبتلا به آسيب ويزه زبانى با همتايان طبيعى

\begin{tabular}{|c|c|c|c|c|c|}
\hline $\mathbf{p}$ & $\mathbf{t}$ & انحراف معيار & ميانگين & فراوانى & گروه \\
\hline \multirow{2}{*}{.$/ . t t$} & \multirow{2}{*}{$r / \Delta \Lambda$} & $f / \cdot q$ & $\Delta N / V \Delta$ & $\wedge$ & طبيعى \\
\hline & & $1 \cdot / 4 r$ & $\uparrow \wedge / \Delta$. & $\wedge$ & آسيب ويزه زبانى \\
\hline
\end{tabular}

جدول أ. تفاوت ميزان كاربرد حروف اضافه مكانى در كودكان مبتلا به آسيب ويزه زبانى با همتايان طبيعى

\begin{tabular}{|c|c|c|c|c|c|}
\hline $\mathbf{p}$ & $\mathbf{t}$ & انحراف معيار & ميانگين & فراوانى & تروه \\
\hline \multirow{2}{*}{$\cdot / \cdot Y V$} & \multirow{2}{*}{$T / F V$} & $\Delta / / F$ & $V N / T \Delta$ & $\wedge$ & طبيعى \\
\hline & & $11 / 1 V$ & $s \vee / 0$. & $\wedge$ & آسيب ويزه زبانى \\
\hline
\end{tabular}

جدول ه. تفاوت ميزان درى حروف اضافه مكانى و غير مكانى در كودكان مبتلا به آسيب ويزه زبانى

\begin{tabular}{|c|c|c|c|c|c|}
\hline $\mathbf{p}$ & $\mathbf{t}$ & انحراف معيار & ميانَين & فراوانى & تروه \\
\hline \multirow{2}{*}{. } & \multirow{2}{*}{$-1 / \% 9$} & r & rו & $\Delta$ & طبيعى \\
\hline & & f & 10 & $\Lambda$ & آسيب ويزه زبانى \\
\hline
\end{tabular}

جدول צ. تفاوت ميزان كاربرد حروف اضافه مكانى و غير مكانى در كودكان مبتلا به آسيب ويزه زبانى

\begin{tabular}{|c|c|c|c|c|c|}
\hline $\mathbf{p}$ & $\mathbf{t}$ & انحراف معيار & ميانگين & فراوانى & تروه \\
\hline \multirow{2}{*}{. } & \multirow{2}{*}{$-r / \Delta \mid Q$} & $1 \cdot / 4 \pi$ & $\hat{N N / D .}$. & $\Delta$ & طبيعى \\
\hline & & $11 / 1 V$ & $s \vee / 0$. & $\wedge$ & آسيب ويثه زبانى \\
\hline
\end{tabular}

دستورى در كفتار كودكان فارسى زبان مبتلا به آسيب ويزه زبانى (ه )، تفاوت ميانگين طول كفته (Length of Utterance) در كودكان مبتلا به آسيب ويزه زبانى در مقايسه با همتايان طبيعى (• (1)، فقدان فرايند كامل معنىشناختى در كودكان مبتلا به آسيب ويزه زبانى (Y l )، اختلالات در يردازش شنيدارى و تفاوت در عملكرد و آناتومى بخشهايى از دستخاه
با استناد بر يزوهشهاى ييشين كه صرفا مطالعاتى زبانى و نه بالينى بودهاند، شايد بتوان اين مطالعه را در زمره يزوهشهاى نوينى قرار داد كه با رويكرد شناختى به مسائل مشترك زبانى و بالينى مىيردازد. آسيب ويزه زبانى و حروف اضافه در زبان فارسى صرفا از منظر زبانشناختى و يا بالينى مورد توجه مطالعات ييشين قرار گرفته است. كاربرد تكىوازهاى 


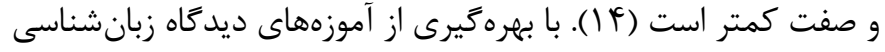
شناختى، استعارههاى مفهومى بيانگر وازمهاى فضايى همجون البالا و

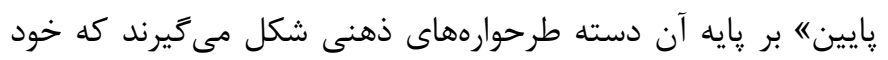

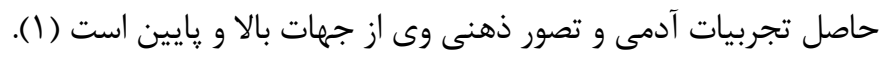

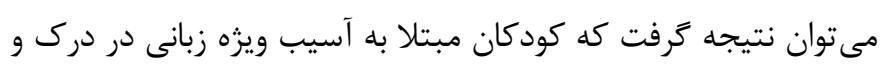

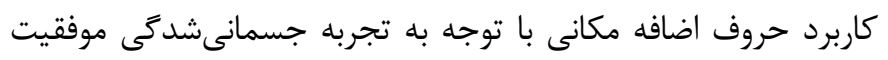
بيشترى نسبت به حروف اضافه غيرمكانى كه صرفا فضاساز هستند، دارند. به عبارت ديكر حروف اضافه مكانى بيان اين مزيت برخوردارند كه نشانَر روابطى هستند كه به طور مستقيم

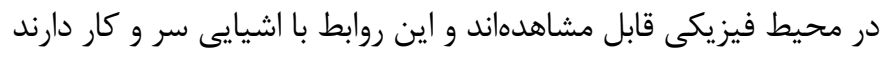

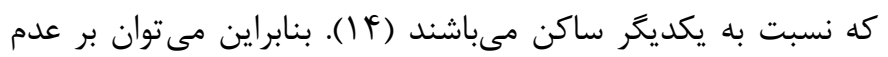

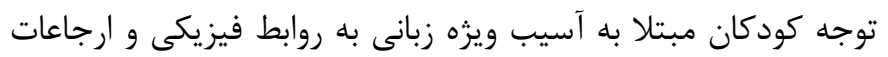

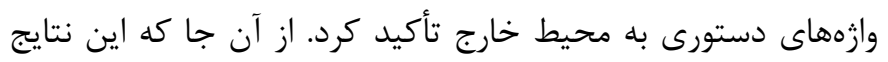

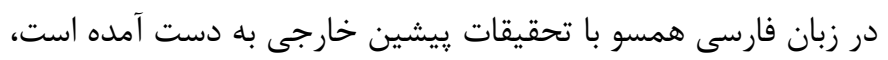

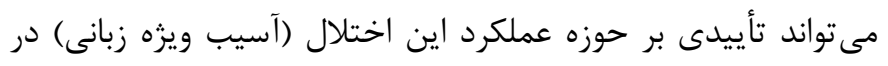

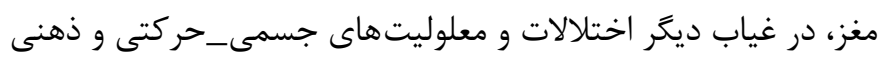

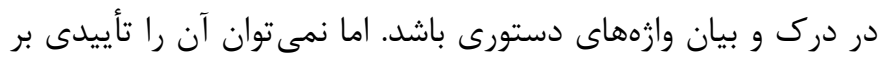

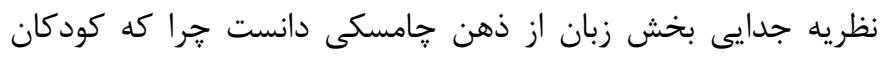

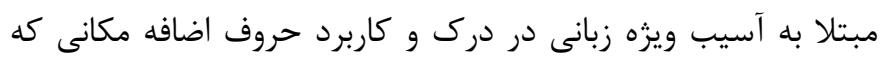
به لحاظ شناختى بدن مند هستند و وازمهاى فضايى به شمار مي آيند نسبت به حروف اضافه غيرمكانى كه صرفا فضاساز هستند، موفقيت بيشترى كسب نمودند. يزوهش در حوزه زبانشناسى بالينى و آسيب شناسى زبان و كَفتار به دليل

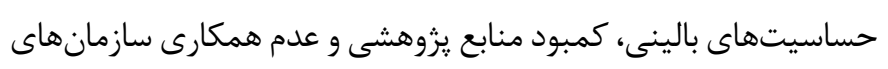

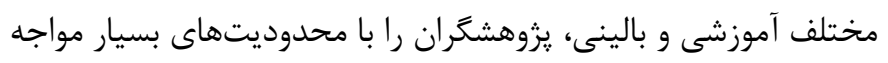

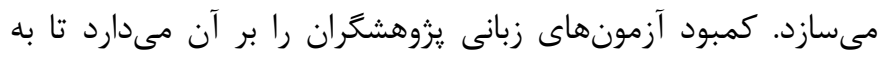

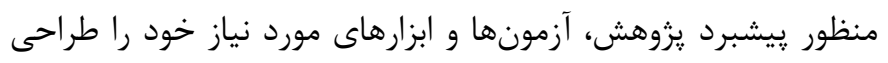

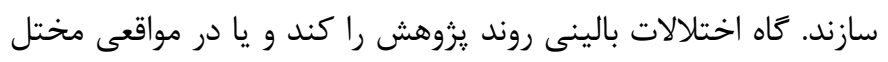

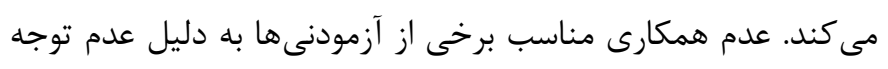

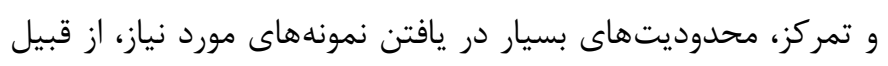

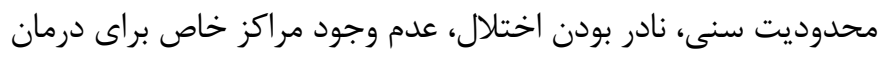

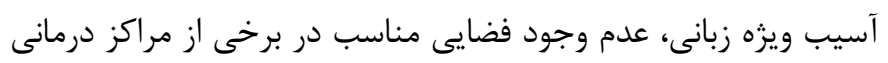

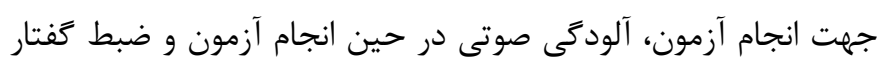

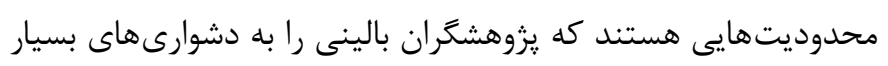

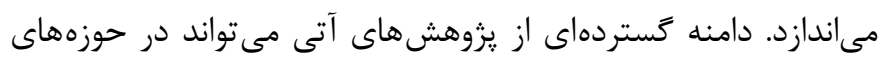

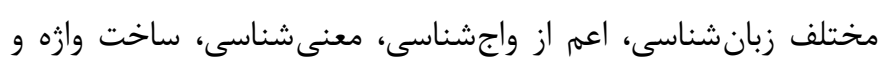

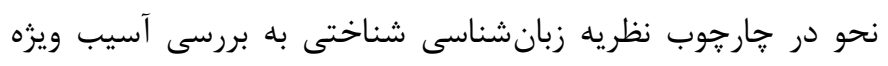

عصبى شنوايى مركزى در كودكان مبتلا به آسيب ويزه زبانى (1)،

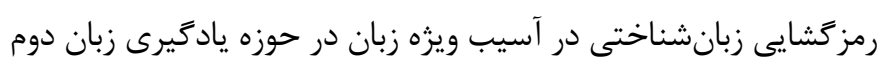

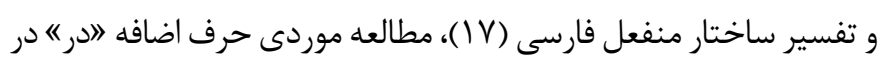

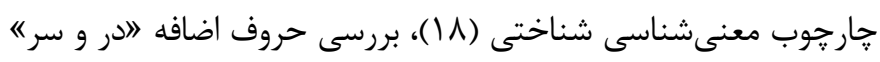

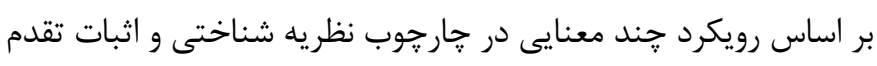

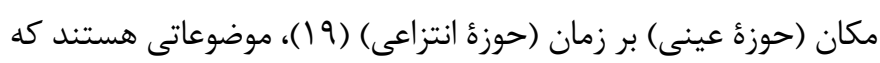

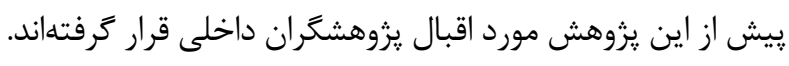

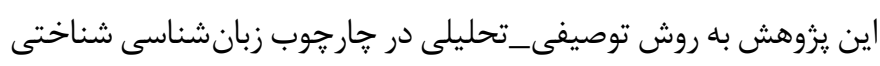

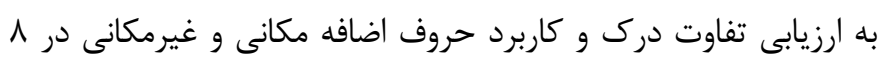

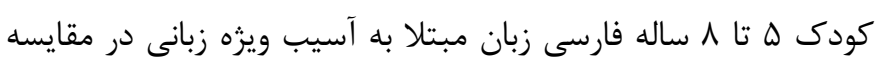
با 1 همتاى طبيعى يرداخته است. يافتههاى حاصل از آزمون محقق فانق ساخته زبان فارسى درك و كاربرد حروف اضافه ساده، همسو با مطالعات ديكر نشان دادند كه ميزان درك و كاربرد حروف اضافهى ساده مكان مكانى

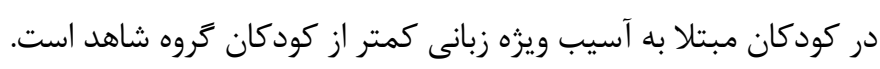
Grela يا عدم انتخاب صحيح حروف اضافه ناشى از اختلالات دستورى كودكان

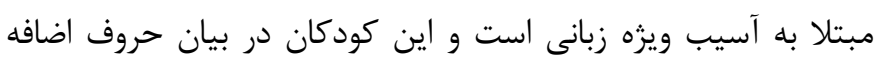

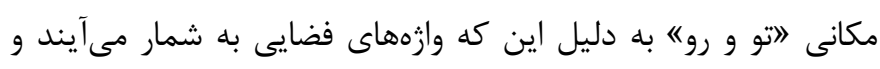

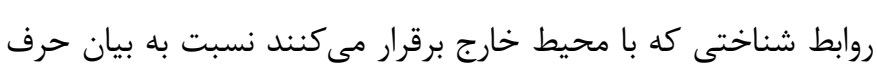

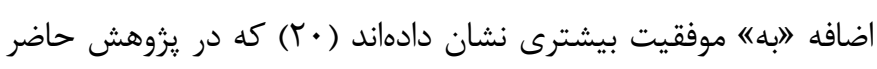

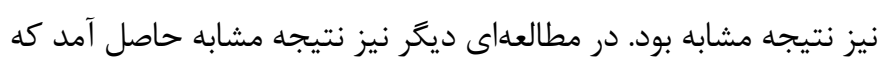

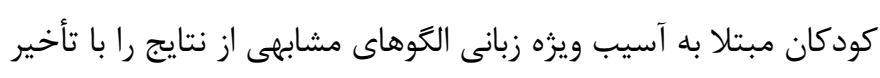

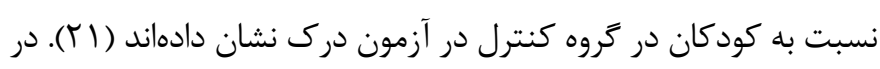

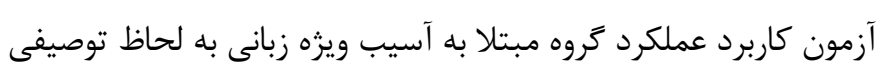

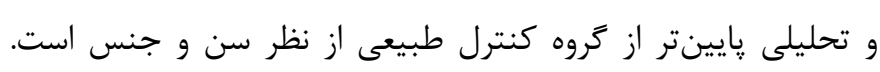

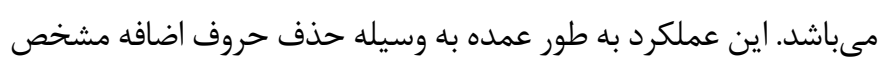

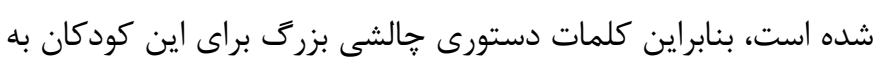

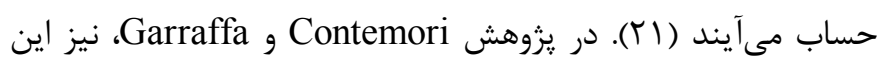

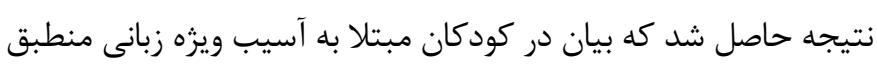
با كودكان طبيعى نيست و اين تفاوت، ويزَّى هاى مربوط به به تمايزات

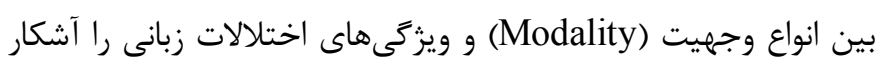

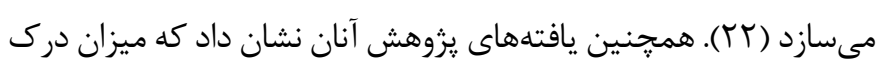

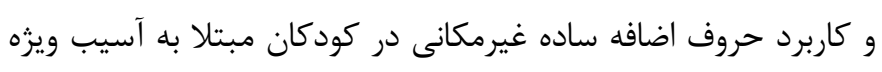

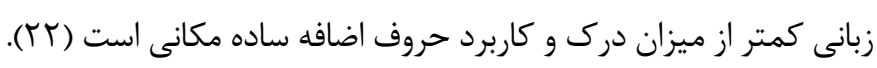

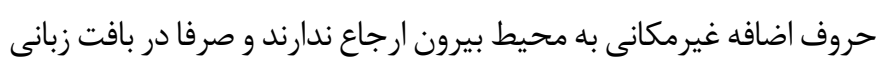

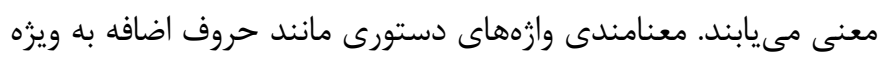

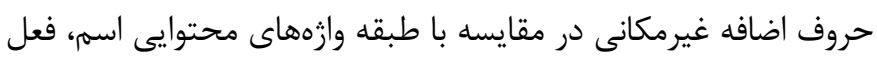


در تأييد عملكرد غيرحوزهاى مغز، كودكان مبتلا به آسيب ويزه زبانى در درك و استفاده از حروف اضافه مكانى اختلالات كمترى نسبت به غيرمكانى ها نشان دادند. تشكر و قلرواذى اين مختصر سببى است تا از دريجه آن كمال سياس و قدردانى خود را از كودكان و والدينى به جاى آوريم كه در اين راه نه جندان هموار هميا و همدل بودند. كود كان مبتلا به آسيب ويزه زبانى و كودكان طيف

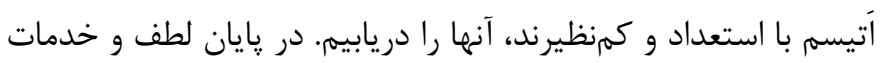

$$
\text { اساتيد فرهيختهام را ياس مى بـارم. }
$$

\section{References}

1. Taylor JR, Littlemore J. The Bloomsbury companion to cognitive linguistics. [Farashi F, Farashi N, Trans]. Tehran:Nevise Parsi;2017. (Persian)

2. Rasekh Mahnad M. An introduction to cognitive linguistics: Theories and concepts. 2nd ed. Tehran:Samt;2014. (Persian)

3. Nilipoor R. Cognitive linguistics. Tehran:Hermes;2018. (Persian) 4. Lewis BA, Thompson LA. A study of developmental speech and language disorders in twins. Journal of Speech, Language, and Hearing Research. 1992;35(5):1086-1094.

5. Bishop DV, North T, Donlan C. Genetic basis of specific language impairment: Evidence from a twin study. Developmental Medicine \& Child Neurology. 1995;37(1):56-71.

6. Buckwalter JA. Articular cartilage: Injuries and potential for healing. Journal of Orthopaedic \& Sports Physical Therapy. 1998;28(4):192-202.

7. Zeesman S1, Nowaczyk MJ, Teshima I, Roberts W, Cardy JO, Brian J, et al. Speech and language impairment and oromotor dyspraxia due to deletion of $7 q 31$ that involves FOXP2. American Journal of Medical Genetics Part A. 2006;140(5):509-514.

8. Nilipoor R. The test of specific language impairment. Tehran:The University of Rehabilitation and Orthopaedic Press;2002. (Persian)

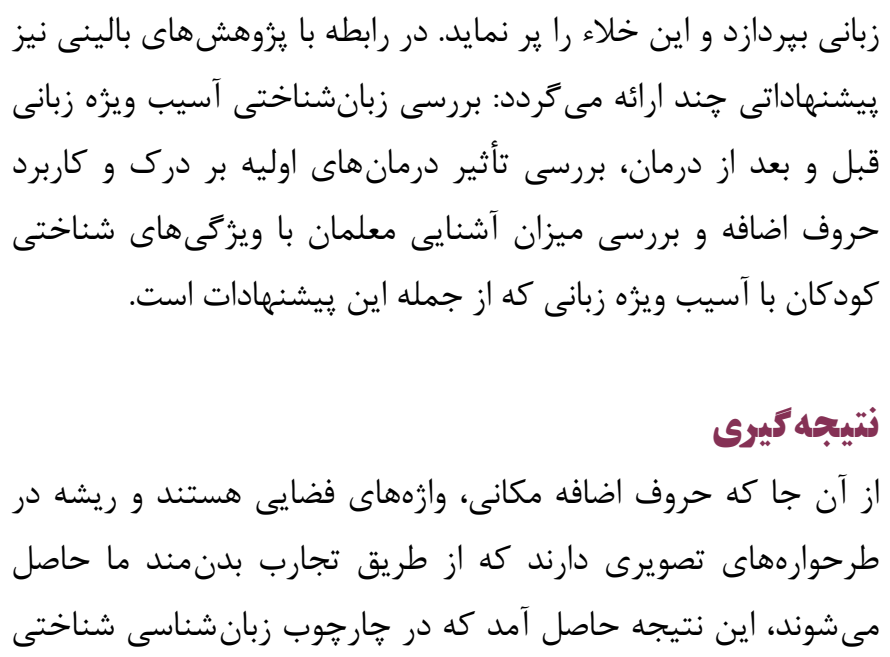

9. Norbury CF, Tomblin JB, Bishop DV. Understanding developmental language disorders: From theory to practice. Cambridge:Cambridge University Press;2008.

10. Maleki Shahmahmood T, Soleymani Z, Jalaei S. A comparison study in Test of Language Development (TOLD) and speech samples between children with specific language impairment and their MLU matched group. Journal of Modern Rehabilitation. 2009;2(3):25-33. (Persian)

11. Mohammadi M, Nilipour R, Shirazi TS, Rahgozar M. Semantic differences of definitional skills between Persian speaking children with specific language impairment and normal language developing children. Archives of Rehabilitation. 2011;12(2):48-55. (Persian)

12. Vinson B. Language disorders across the lifespan. 3rd ed. New York:Cengage Learning;2007.

13. Farhadi H. Research methods in applied lingaistic. Tehran:Rahnama;2009. (Persian)

14. Steinberg D. An introduction to psycholinguistics. [Golfam A, Trans]. Tehran:Samt;2019. (Persian)

15. Naseh MA, Dabirmoghadam M. The abstracts of linguistic thesis of national and Islami Azad Universities. Tehran:Allameh Tabatabaie University Press;2000. (Persian)

16. Nikravesh M, Aghajanzade M. Auditory processing in spe- 
cific language impairment. Journal of Paramedical Sciences \& Rehabilitation. 2013;2(2):42-53. (Persian)

17. Hoseini A. Grammar-Specific language impairment (G-SLI): A study in foreign language learning [MA Thesis]. Mashhad:Ferdowsi University;2014. pp. 207. (Persian)

18. Golfam A, Yusefirad F. A cognitive semantic approach to Persian spatial prepositions, a pedagogical perspective, case study: Persian preposition/dær/. Pazhuhesh-e Zabanha-ye Khareji. 2010;56:167-179. (Persian)

19. Rasekh Mahand M, Ranjbar Zarrabi N. The semantic networks of two prepositions Dar and Sar. Journal of Compara- tive Linguistic Researches. 2013;3(5):95-111. (Persian)

20. Grela B, Rashiti L, Soares M. Dative prepositions in children with specific language impairment. Applied Psycholinguistics. 2004;25(4):467-480.

21. Marina LP, Befi-Lopes DM, Takiuchi N. Use and comprehension of prepositions by children with specific language impairment. Pro-fono: Revista De Atualizacao Cientifica. $2005 ; 17(3): 331-343$.

22. Contemori C, Garraffa M. Comparison of modalities in SLI syntax: A study on the comprehension and production of non-canonical sentences. Lingua. 2010;120(8):1940-1955. 